\title{
REKONSTRUKSI PENGUMUMAN LELANG MELALUI MEDIA SURAT KABAR HARIAN PADA LELANG NONEKSEKUSI SUKARELA
}

Aditya Wirawan $^{1}$ dan Donarin ${ }^{2}$

Politeknik Keuangan Negara STAN

Alamat Korespondensi: adityawirawan@pknstan.ac.id

Diterima Pertama

[19 Mei 2021]

Dinyatakan Diterima

[26 Juni 2021]

KATA KUNCI:

lelang noneksekusi sukarela, pengumuman lelang, rekonstruksi hukum
The provision of auction announcements through the daily newspaper media on voluntary non-execution auctions has several weaknesses and problems. This provision indicates that there is a special right granted by the government to one business actor that ruins the concept of democracy in fair business competition. Besides that, the position of regulations related to this provision is still unclear in the hierarchy of statutory regulations in Indonesia. The highest regulation which governs the auction itself is no longer relevant to the nation's goals contained in the 1945 Constitution of Republic Indonesia. In the implementation of this provision, the auction seller faces problems that the daily newspaper media is ineffective and inefficient to achieve the main aim of the auction announcement. These weaknesses and problems bring out the new legal needs in the community. The government as a regulator needs to carry out legal reconstruction to fulfill that legal needs. The law is the most appropriate form to contain that new legal needs. During the process of forming the new law, the government needs to synchronize and harmonize it with other laws to avoid regulatory overlap.

Ketentuan pengumuman lelang melalui media surat kabar harian pada lelang noneksekusi sukarela memiliki beberapa kelemahan dan permasalahan. Ketentuan tersebut mengindikasikan adanya hak istimewa yang diberikan pemerintah pada satu pelaku usaha yang menciderai konsep demokrasi dalam persaingan usaha yang sehat. Selain itu, kedudukan peraturan terkait kententuan tersebut masih abu-abu dalam hierarki peraturan perundang-undangan di Indonesia. Peraturan tertinggi yang mengatur lelang sendiri pun sudah tidak relevan dengan tujuan Indonesia yang terdapat dalam Undang-undang Dasar 1945. Dalam pelaksanaan ketentuan tersebut, penjual lelang dihadapkan pada masalah bahwa media surat kabar harian sudah tidak efektif dan efisien untuk mencapai tujuan utama pengumuman lelang. Kelemahan dan permasalah tersebut mendorong kebutuhan hukum baru dalam masyarakat. Pemerintah sebagai regulator perlu melakukan rekonstruksi hukum untuk memenuhi kebutuhan hukum tersebut. Undang-undang menjadi bentuk yang paling tepat untuk memuat pembaharuan hukum tersebut. Dalam proses pembentukan undang-undang baru tersebut, pemerintah perlu melakukan sinkronisasi dan harmonisasi dengan undang-undang yang lain untuk menghindari tumpang tindih peraturan. 


\section{PENDAHULUAN}

\subsection{Latar Belakang}

Sebagai negara yang sebagian besar pertumbuhan ekonominya dipengaruhi oleh konsumsi masyarakat dan belanja pemerintah, lelang menjadi salah satu faktor penunjang pembangunan perekonomian nasional. Lelang memiliki salah satu fungsi sebagai fungsi budgeter. Lelang memberikan kontribusi terhadap penerimaan negara berupa bea lelang maupun penerimaan lainnya seperti BPHTB dan PPN. Adanya lelang juga dapat meningkatkan nilai barang karena pada dasarnya lelang menghasilkan harga yang kompetitif. Selain itu, lelang juga mempermudah dan memperluas transaksi barang atau jasa yang ada di dalam masyarakat. Secara tidak langsung, lelang menjadi sarana untuk mencapai salah satu tujuan negara yang tercantum dalam Pembukaan Undang-undang Dasar Negara Republik Indonesia Tahun 1945 yaitu memajukan kesejahteraan umum.

Saat ini, lelang di Indonesia diatur dalam beberapa peraturan. Akan tetapi, Vendu Reglement tetap menjadi peraturan tertinggi yang mengatur tata cara pelaksanaan lelang. Pada faktanya terdapat beberapa ketentuan dalam peraturan-peraturan tersebut yang kurang sinkron dengan Vendu Reglement. Salah satu contohnya adalah ketentuan terkait pengumuman lelang yang diatur dalam Peraturan Menteri Keuangan Nomor 27/PMK.06/2016. Vendu Reglement tidak mengatur pengumuman lelang secara tegas. Pasal 20 alinea 6 Vendu Reglement justru memberi isyarat bahwa kewajiban menunjukkan adanya bukti pengumuman lelang hanya untuk lelang eksekusi benda tidak bergerak sitaan pengadilan sehingga seolah tidak ada kewajiban untuk melakukan pengumuman lelang untuk jenis lelang lainnya.

Pasal 58 dan 59 Peraturan Menteri Keuangan Nomor 27/PMK.06/2016 tentang Petunjuk Pelaksanaan Lelang mengatur ketentuan pengumuman lelang melalui media surat kabar harian pada lelang noneksekusi sukarela. Pada pasal 58 disebutkan bahwa pengumuman lelang atas barang bergerak, barang tidak bergerak, dan barang bergerak yang dijual bersama barang tidak bergerak dilakukan melalui surat kabar harian. Selanjutnya pada pasal 59 disebutkan bahwa penjual dapat melakukan pengumuman lelang melalui media tempelan atau media elektronik dengan syarat nilai limit lelang maksimal Rp50.000.000,00 dan terdapat permintaan dari penjual yang di dalamnya memuat alasan menggunakan media tersebut.

\footnotetext{
${ }^{1}$ L. M. Friedman, The Legal System: A Social Science Perspective, diterjemahkan oleh M. Khozim, (Bandung: Nusa Media, 2013), hal.213.
}

Dari pasal-pasal tersebut dapat diketahui bahwa pemerintah telah memberikan hak istimewa kepada pelaku usaha industri surat kabar harian sebagai media utama untuk melakukan pengumuman lelang. Adanya hak istimewa tersebut jelas menimbulkan perbedaan kesempatan berusaha bagi pelaku usaha industri lainnya yang sebenarnya dapat menjalankan fungsi surat kabar harian sebagai media untuk menyebarluaskan informasi lelang.

Pasal-pasal tersebut juga menimbulkan suatu kewajiban yang tidak lagi relevan dengan perkembangan. Pada zaman sekarang sebagian besar masyarakat dan peserta lelang tidak lagi mengakses informasi melalui surat kabar harian. Sebagai contoh, pada lelang yang diajukan oleh PT JBA Indonesia, sebagian besar peserta lelang mendapatkan informasi lelang secara langsung dari kantor cabang dengan media sales promotion item berupa flyer, poster, banner, ataupun pemberitahuan langsung dari Tim Customer Care.

Kelemahan dalam peraturan terkait lelang khususnya terkait ketentuan pengumuman lelang noneksekusi sukarela serta perkembangan di masyarakat mendorong kebutuhan hukum baru. Pemenuhan kebutuhan hukum tersebut dapat dilakukan dengan rekonstruksi hukum. Rekonstruksi tersebut merupakan upaya nyata untuk mengharmoniskan dan menyinkronkan peraturan lelang yang ada di Indonesia sekaligus memperkuat fungsi dan kelembagaan lelang.

\section{KERANGKA TEORI}

\subsection{Sistem Hukum dalam Perspektif IImu Sosial}

Tidak ada definisi riil terkait sistem hukum ${ }^{1}[\mathrm{u} 1]$. Hal yang pasti adalah bahwa sistem tersebut terdiri dari subsistem-subsistem atau komponen yang terhubung dengan negara. Komponen tersebut berupa legal structure, legal substance, dan legal culture. Ketiganya biasa disebut sebagai tiga unsur sistem hukum. Unsur-unsur tersebut saling berinteraksi dan membentuk sistem hukum yang beroperasi secara aktual.

Hukum sendiri dibentuk atas dasar kedaulatan rakyat sehingga seharusnya hukum ada untuk melayani rakyat atau masyarakat. Hukum yang melayani kebutuhan masyarakat dimaksudkan agar hukum tersebut tidak tertinggal oleh lajunya perkembangan masyarakat. Pernyataan ini sejalan dengan teori terkait asal-usul hukum yang bersifat umum yaitu teori sosial. Dalam teori tersebut, nilai dan konsep hukum muncul dari masyarakat. Teori sosial mengandung satu prinsip fundamental bahwa hukum yang hidup akan menunjukkan jejak kekuatan 
REKONSTRUKSI PENGUMUMAN LELANG MELALUI

MEDIA SURAT KABAR HARIAN PADA LELANG

NONEKSEKUSI SUKARELA

Aditya Wirawan ${ }^{1}$ dan Donarin ${ }^{2}$

sosial. Ketika keseimbangan kekuatan sosial bergeser ke arah perubahan maka hukum juga akan berubah.

Kekuatan sosial dapat mengubah hukum dapat digambarkan dengan opini publik. Akan tetapi, opini publik tidak selalu menggambarkan kekuatan sosial yang sebenarnya memengaruhi hukum. Misalnya terdapat opini publik bahwa suatu peraturan bersifat tidak rasional. Opini tersebut pada akhirnya berhasil mengubah peraturan tersebut. Perubahan tersebut sejatinya bukan karena opini tersebut sangat meyakinkan melainkan karena masyarakat memang telah bergerak meninggalkan kebiasaan mereka yang lama dan tengah bergerak ke arah pola kebiasaan baru yang membutuhkan peraturan baru dengan fungsi dan kedudukan yang pasti.

Kekuatan sosial yang mendorong perubahan terhadap hukum termasuk dalam salah satu tipe perubahan hukum menurut Friedman ${ }^{2}$, yaitu perubahan yang berawal dari luar dan memberikan dampak kepada masyarakat. Ketika suatu hukum dirasa sudah tidak sesuai lagi dengan masyarakat maka hukum harus diubah untuk memberikan pedoman baru yang sesuai dengan perkembangan masyarakat. Perubahan ini dilakukan dengan jalan planning dan distruption, misalnya dengan melakukan penyederhanaan format dan formalitas hukum serta pemangkasan berbagai kebiasaan dan ketentuan yang lama.

Upaya planning dan distruption tersebut erat kaitannya dengan rekontruksi hukum. Dalam Kamus Besar Bahasa Indonesia versi Daring, rekonstruksi diartikan sebagai penyusunan atau penggambaran kembali. Maka dari itu, rekonstruksi hukum dapat dimaknai sebagai suatu proses untuk menyusun kembali atau menata ulang hukum dalam upaya law reform maupun law development.

\subsection{New Public Management}

Birokrasi di organisasi publik cenderung bersifat statis, kaku, dan formal. Organisasi publik dianggap enggan untuk maju karena organisasi ini melakukan kegiatan dan tugasnya tanpa perubahan ataupun inovasi yang membuat organisasi tersebut menjadi lebih baik. Pada organisasi publik bisa saja terjadi capacity gap antara kemampuan birokrasi dengan kemampuan yang seharusnya dimiliki birokrasi untuk dapat merespon perkembangan kebutuhan masyarakat. Fakta tersebut membuat konsep-konsep pada birokrasi pada organisasi bisnis dilirik untuk dijadikan acuan untuk melakukan perubahan dan

\footnotetext{
2 Ibid., hal.253-254.

3 David Osborne dan Ted Gaebler, Reinventing Government: How the Entrepreneurial Spirit Is
}

perbaikan pada organisasi publik. Semangat reformasi tersebut dikenal dengan istilah New Public Management (NPM).

Tidak ada definisi yang mutlak atas konsep New Public Management karena pada perkembangannya terdapat berbagai pendapat yang menggambarkan wujud, cara kerja, dan bagaimana seharusnya NPM itu. Akan tetapi, pendapat yang dikemukakan oleh Osborne dan Gaebler yang dikenal sebagai Reinventing Government dianggap paling dapat menggambarkan New Public Management.

Reinventing Government dimaknai sebagai penciptaan kembali birokrasi publik dengan konsep beracuan pada organisasi bisnis yang efektif, efisien, mudah beradaptasi, dan punya kemampuan untuk berinovasi. Penciptaan kembali tersebut dibarengi dengan perubahan tujuan, insentif, akuntabilitas, power structure, dan budaya dalam organisasi publik. Reinventing Government bertujuan untuk menciptakan organisasi-organisasi dan sistem publik yang terbiasa memperbarui dan memperbaiki kualitasnya secara berkelanjutan tanpa adanya dorongan dari luar sehingga organisasi publik menjadi selalu siap menghadapi tantangan dan perubahan yang terjadi di masa depan.

Osborne dan Gaebler menawarkan beberapa prinsip bisnis yang seharusnya dimasukan dalam kegiatan sektor publik ${ }^{3}$. Prinsip-prinsip tersebut yaitu:

1. Pemerintah hanya katalis;

2. Pemerintah adalah milik rakyat;

3. Pemberdayaan kompetisi;

4. Pemerintah yang digerakkan oleh misi;

5. Pemerintah yang berorientasi pada hasil;

6. Berorientasi pelanggan bukan birokrasi;

7. Semangat wirausaha;

8. Antisipatif;

9. Terdesentralisasi;

10. Berorientasi pada pasar.

Konsep Reinventing Government tersebut tidak boleh diterapkan secara murni di Indonesia karena konsep tersebut merujuk pada kasus-kasus di Amerika Serikat yang memiliki perbedaan kondisi dan karakteristik dengan Indonesia. Maka dari itu, penerapan Reinventing Government di Indonesia dapat dilakukan secara parsial. Terdapat banyak konteks seperti ekonomi, sosial, politik, dan budaya yang harus diperhatikan dalam menerapkan konsep tersebut.

Penerapan konsep Reinventing Government di Indonesia juga menghadapi tantangan. Salah satunya

Transforming the Public Sector, diterjemahkan oleh Abdul Rosyid, (Jakarta: Pustaka Binaman Pressido, 1996), hal.19-20.

Halaman 3 
REKONSTRUKSI PENGUMUMAN LELANG MELALUI MEDIA SURAT KABAR HARIAN PADA LELANG NONEKSEKUSI SUKARELA

Aditya Wirawan $^{1}$ dan Donarin ${ }^{2}$

adalah kolusi, korupsi, dan nepotisme. Pemerintah perlu membenahi hal tersebut untuk mendukung keberhasilan upaya penerapan konsep tersebut. Upaya penerapan konsep Reinventing Government dalam birokrasi pemerintah Indonesia juga harus didukung dengan penyiapan sumber daya manusia yang siap dan mampu mendukung penerapan konsep tersebut, penyesuaian sistem dan prosedur kerja, serta penyempurnaan regulasi atau peraturan yang lebih akomodatif dan fleksibel terhadap perubahan.

\section{METODE PENELITIAN}

Penelitian ini menggunakan pendekatan kualitatif. Data-data diperoleh dari wawancara sebagai sumber data primer dan studi pustaka terhadap peraturan perundang-undangan, buku, jurnal, ataupun publikasi yang berkaitan dengan topik yang dibahas sebagai sumber data sekunder.

Teknik analisis data yang digunakan mengacu pada metode yang diperkenalkan Miles dan Huberman. Aktivitas dalam analisis data meliputi reduksi data (data reduction), penyajian data (data display), serta penarikan simpulan (conclusion drawing) (Miles \& Huberman, 2007) ${ }^{4}$. Tahap reduksi data merupakan tahap yang dilakukan untuk merangkum, memilih hal-hal yang pokok, memfokuskan pada hal-hal yang penting, serta mencari tema dan polanya. Penulis akan memilah informasi yang diperoleh mana yang sesuai dan yang tidak sesuai dengan fokus permasalahan yang diteliti dan tujuan penulisan. Pada tahap penyajian data, Penulis berusaha menyusun data yang relevan sehingga menjadi informasi yang dapat disimpulkan dan memiliki makna tertentu. Pada tahap penarikan simpulan, Penulis menarik simpulan dari hasil penyajian data. Simpulan penelitian kualitatif mengarah kepada jawaban rumusan masalah yang diajukan sebelumnya.

Kemudian untuk menguji validitas data, Penulis menggunakan analisis triangulasi. Analisis triangulasi dilakukan dengan cara menganalisis jawaban subjek kemudian meneliti kebenarannya dengan menyandingkannya dengan data empiris atau sumber data lain yang tersedia (Kriyantono, 2006) ${ }^{5}$.

\footnotetext{
${ }^{4}$ Matthew B. Miles dan A. Michael Huberman, Analisis Data Kualitatif, (Jakarta: Universitas Indonesia, 2007), hal.173-174.

${ }^{5}$ Rachmat Kriyantono, Teknik Praktis Riset Komunikasi, (Jakarta: PT Kencana Perdana, 2006), hal.72.

6 Nibras Nada Nailufar, "Akankah TV Bernasib Sama Dengan Koran Dan Majalah?", diakses dari https://www.kompas.com/tren/read/2019/08/24/071
}

\section{HASIL PENELITIAN}

\subsection{Permasalahan dalam Pelaksanaan Pengumuman Lelang Noneksekusi Sukarela}

Dalam pelaksanaan pengumuman lelang noneksekusi sukarela melalui surat kabar harian, penjual lelang dihadapkan pada masalah utama terkait bagaimana efektivitas dan efisiensi pengumuman yang mereka lakukan. Efektivitas diartikan sebagai suatu ukuran yang memberikan gambaran seberapa jauh tujuan atau target yang sudah ditetapkan sebelumnya dapat tercapai. Sedangkan efisiensi diartikan sebagai suatu ukuran keberhasilan suatu kegiatan yang diukur berdasarkan besarnya biaya atau sumber daya yang digunakan untuk mencapai tujuan atau hasil yang diinginkan. Penjual merasa pengumuman lelang melalui surat kabar harian tersebut tidak efektif dan efisien.

Tujuan utama dari pelaksanaan pengumuman lelang adalah penyebarluasan informasi lelang. Ketika informasi tersebut tersebar luas dan semakin banyak orang yang mengikuti lelang maka dapat dikatakan pengumuman lelang yang telah dilakukan tergolong efektif atau tingkat efektivitasnya tinggi.

Dahulu surat kabar dianggap sebagai media massa yang utama untuk menyampaikan informasi kepada masyarakat sebelum terdapat berbagai bentuk media massa lainnya. Seiring dengan perkembangan zaman, teknologi informasi dan komunikasi pun juga ikut berkembang. Kebiasaan masyarakat untuk mengakses informasi pun juga ikut bergeser. Berdasarkan survei Global Web Index ${ }^{6}$ dari tahun 2014 s.d. 2018 terhadap 391.130 responden di seluruh dunia, media cetak seperti surat kabar dan majalah hanya dibaca rata-rata 43 menit per hari. Angka tersebut termasuk angka yang kecil jika dibandingkan dengan media lain misalnya media online yang dibaca rata-rata 6 jam 45 menit per hari. Dari hal tersebut dapat diketahui bahwa kebiasaan masyarakat untuk mengakses informasi telah bergeser kearah media online yang diakses melalui internet.

Survey Nielsen Consumer Media View ${ }^{7}$ yang dilakukan terhadap 17.000 responden di sebelas kota di Indonesia pada tahun 2017 menghasilkan data penetrasi media sebagai berikut.

300965/akankah-tv-bernasib-sama-dengan-koran-danmajalah?page=all, pada tanggal 23 Juni 2020 pukul 20.00 WIB.

7 Nielsen.com, "Tren Baru Di Kalangan Pengguna Internet Di Indonesia.", diakses dari https://www.nielsen.com/id/en/pressreleases/2017/tren-baru-di-kalangan-pengguna- 


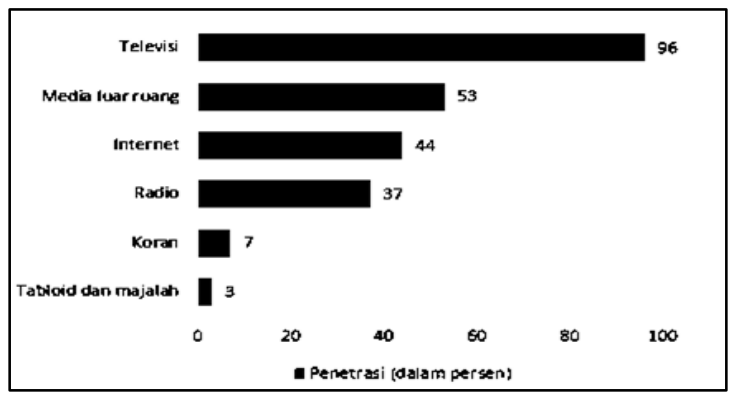

Gambar 4.1.1 Grafik Penetrasi Media di Indonesia Tahun 2017[u2] (Diolah dari Press Release Nielsen Indonesia)

Dari gambar tersebut, dapat diketahui bahwa penetrasi koran atau surat kabar hanya sebesar $7 \%$. Persentase tersebut tergolong rendah jika dibandingkan dengan media lain seperti radio, internet, media luar ruang, dan televisi. Apalagi persentase sebesar 7\% tersebut masih dibagi berdasarkan jenis-jenis surat kabar. Persentase penetrasi surat kabar harian yang merupakan salah satu jenis surat kabar tentunya lebih rendah dari $7 \%$. Maka dari itu, pencapaian tujuan untuk menyebarluaskan informasi pelaksanaan lelang termasuk lelang noneksekusi sukarela tidak lagi maksimal jika menggunakan surat kabar harian sebagai media pengumuman lelang. Atau dengan kata lain, efektivitas pengumuman lelang noneksekusi sukarela melalui media surat kabar harian tergolong rendah. Hal ini sejalan dengan pernyataan narasumber yang bertindak sebagai penjual, bahwa:

“...kalau kita lihat dari efektifitas, tingkat efektifitasnya memang tidak efektif walaupun biayanya cukup besar." (Wawancara dengan Bapak Michael Philipus, Marketing and Customer Care Section Head PT JBA Indonesia, tanggal 10 April 2020, Pukul 10.00)

Dalam pencapaian tujuan pengumuman lelang, sumber daya yang utama adalah uang. Uang atau biaya tersebut digunakan untuk membayar pemuatan pengumuman lelang dalam surat kabar harian. Semakin sedikit biaya yang dikeluarkan maka semakin efisien kegiatan tersebut.

Sebagai contoh, biaya yang harus dikeluarkan narasumber yang bertindak sebagai penjual untuk melakukan satu kali pengumuman lelang melalui media surat kabar adalah:

“...kurang lebihnya angkanya di angka 1 sampai 3 juta, sekali event lelang. Artinya satu tanggal, satu cabang, satu event, karena kita punya dua

internet-di-indonesia/, pada tanggal 25 Juni 2020 pukul 21.00 WIB.

${ }^{8}$ The State Council. (2014). Auction Law of the People's Republic of China. event ya, itu ada yang motor ada yang mobil." (Wawancara dengan Bapak Michael Philipus, Marketing and Customer Care Section Head PT JBA Indonesia, tanggal 10 April 2020, Pukul 10.00)

Jika melihat dampaknya dalam upaya penyebarluasan informasi lelang yang tidak sesignifikan media lain yang juga digunakan, media surat kabar harian ini memakan biaya yang besar sehingga selain efektivitasnya rendah, efisiensinya juga rendah.

Masalah lainnya timbul ketika penjual harus melakukan ralat pengumuman lelang. Ralat pengumuman lelang ini dilakukan ketika terjadi kesalahan redaksional ataupun penambahan informasi lainnya. Ralat pengumuman lelang tersebut harus diumumkan maksimal satu hari kerja sebelum pelaksanaan lelang. Media yang digunakan dalam ralat pengumuman lelang harus sama dan merujuk pada media pengumuman lelang sebelumnya sehingga hal tersebut menambah biaya yang harus dikeluarkan penjual dan memperbesar inefisiensi.

Terlepas dari berbagai masalah yang dihadapi penjual dalam melaksanakan pengumuman lelang noneksekusi sukarela melalui media surat kabar harian, kegiatan tersebut harus tetap dilaksanakan untuk memenuhi aspek hukum pelaksanaan lelang. Lelang tidak dapat dilaksanakan tanpa didahului pengumuman lelang. Bahkan ketika terdapat indikasi ketidaksesuaian pengumuman lelang yang dilakukan dengan ketentuan, maka lelang akan mengalami cacat hukum dan rawan gugatan.

Untuk mengatasi berbagai masalah tersebut, pemerintah dapat mengadopsi mekanisme pengumuman lelang noneksekusi sukarela yang ada di beberapa negara. Di sebagian besar negara, lelang noneksekusi sukarela secara penuh telah diserahkan kepada swasta sehingga pengumuman lelangnya juga menjadi lebih fleksibel sesuai dengan kebutuhan penjual lelang. Penjual lelang bebas memilih media apa yang akan digunakan untuk menyeberluaskan informasi lelang.

Ketentuan lelang di Republik Rakyat Tiongkok diatur dalam The Auction Law of the People's Republic of China $^{8}$. Peraturan tersebut dihasilkan pada masa pemerintahan Presiden Jiang Zemin melalui $20^{\text {th }}$ Meeting of the Standing Committee of the $8^{\text {th }}$ National People's Congress pada 5 Juli 1996. Ketentuan dalam peraturan tersebut mulai berlaku sejak tanggal 1[u3]

http://english.www.gov.cn/archive/laws_regulations/2 014/08/23/content_281474982987372.htm 
REKONSTRUKSI PENGUMUMAN LELANG MELALUI MEDIA SURAT KABAR HARIAN PADA LELANG

NONEKSEKUSI SUKARELA

Aditya Wirawan ${ }^{1}$ dan Donarin ${ }^{2}$

Januari 1997. Pada perkembangannya, peraturan tersebut terakhir direvisi melalui $11^{\text {th }}$ session of the Standing Committee of the $10^{\text {th }}$ National People's Congress of the People's Republic of China pada 28 Agustus 2004.

Ketentuan terkait pengumuman lelang diatur dalam Bab Keempat Bagian 2 peraturan tersebut. Sesuai dengan pasal 47 , media yang digunakan untuk melakukan pengumuman lelang dapat berupa surat kabar atau media lainnya. Pengumuman lelang tersebut dilakukan tujuh hari sebelum hari lelang dan harus memuat waktu dan tempat lelang, objek lelang, waktu dan tempat pameran objek lelang, formalitas untuk menjadi peserta, dan keterangan lainnya perlu diumumkan.

Dari ketentuan tersebut, dapat diketahui bahwa pengumuman lelang di Republik Rakyat Tiongkok sifatnya lebih fleksibel. Penjual dapat memilih menggunakan surat kabar atau media lainnya yang akan digunakan sebagai media pengumuman lelang. Pemerintah hanya mengatur jangka waktu penerbitan dan informasi yang harus dimuat dalam pengumuman lelang tersebut.

Di Jepang ${ }^{9}$,[u4] hampir semua jenis lelang sudah dapat diakses melalui internet. Salah satu platform terbesar yang memfasilitasinya adalah Yahoo! Japan. Salah satu inovasi layanan Yahoo! Japan adalah Yahoo! Auction yang dirilis pada tahun 1999. Yahoo! Auction menjadi situs lelang privat terpopuler di Jepang. Berbagai jenis barang ditawarkan di dalamnya, misalnya otomotif, kebutuhan rumah tangga, barang antik, tanaman, dan lain sebagainya. Barang tersebut merupakan milik perorangan atau badan hukum yang telah menjadi user Yahoo! Auction. Pada perkembangannya, Yahoo! Japan juga merilis situs baru yang serupa dengan Yahoo! Auction yaitu Yahoo! Koubai Auction. Situs baru ini menjadi situs lelang pemerintah atas barang sitaan pajak serta barang milik pemerintah. Otoritas pajak dan instansi pemerintah terkait dengan barang yang dijual bertindak sebagai penjual lelang pada situs ini. Selain Yahoo! Japan, terdapat platform lelang internet lainnya yang penggunanya tidak sebanyak Yahoo!. Jenis lelang yang difasilitasi di dalamnya pun hanya lelang privat. Contoh platform lainnya tersebut adalah Mobaoku, Sekaimon, Eco Ring, dan lain sebagainya.

Tidak hanya melalui platform internet, lelang privat juga diselenggarakan oleh balai lelang secara

\footnotetext{
${ }^{9}$ Tamete Fuyasu. (2020). おすすめオークションサイ ト・アプリ! 種類特徵比較まとめ: Aplikasi Situs Lelang yang Disarankan! Jenis Ringkasan Perbandingan Fitur. https://tametefuyasu.com/auction/4314/
}

konvensional. Balai lelang tersebut perlu memperoleh izin dari instansi terkait komoditas yang mereka lelang. Misalnya, jika balai lelang tersebut menjual otomotif bekas seperti Used Car System Solution (USS), Japan Bike Auction (JBA) Yokohama, dan Nissan Auto Auction (NAA) maka balai lelang tersebut harus memperoleh lisensi dari kepolisian sehingga legalitas objek lelangnya terjamin. Sedangkan untuk balai lelang yang menjual tanaman atau pun bunga seperti Ohta Kaki Flower Auction maka balai lelang tersebut harus memperoleh lisensi dari instansi pertanian agar bunga yang mereka jual terjamin mutunya.

Lelang privat ini jika di Indonesia mirip dengan lelang noneksekusi sukarela. Barang-barang yang dijual pada lelang tersebut merupakan barang milik perorangan maupun badan hukum swasta. Jenis barang yang dijual pun beragam mulai yang nilainya kecil seperti elektonik dan furnitur bekas sampai yang nilainya besar seperti otomotif bekas dan properti yang dilelang berdasarkan keinginan sendiri.

Pada platform internet berapa pun nilai barang yang akan dilelang, penyebarluasan informasi lelang dilakukan dengan katalog yang ada pada laman online platform terkait. Katalog tersebut memuat berbagai informasi seperti deskripsi barang, foto, nilai limit, tanggal penawaran dibuka, tanggal penawaran ditutup, identitas penjual dan lain sebagainya. Informasi tersebut diinput sendiri oleh penjual yang sebelumnya sudah terdaftar sebagai user pada platform tersebut.

Pada balai lelang, informasi lelang baik terkait barang yang dilelang atau pun pelaksanaan lelang disebarluaskan dengan media laman website balai lelang terkait, selebaran, bahkan iklan pada televisi. Selain itu, mengingat bahwa mekanisme lelang pada balai lelang di Jepang mengharuskan setiap pihak yang terlibat di dalamnya menjadi member balai lelang, maka informasi lelang juga dapat diberitahukan langsung kepada calon potensial yang dapat menjadi pembeli lelang dari daftar member tersebut.

Dari pemaparan tersebut, dapat diketahui bahwa pengumuman lelang privat di Jepang sifatnya lebih fleksibel. Penjual bebas memilih media apa saja yang mereka gunakan untuk menyebarluaskan informasi lelang. Hal yang paling penting adalah bahwa informasi lelang tersebut dapat tersebar luas.

Di Bangladesh ${ }^{10}$ [u5]yang merupakan negara dengan sistem hukum Common Law, pengumuman

10 All Tender. (2020). All Tender: for all Bangladeshi tenders. https://www.alltender.com/ 
REKONSTRUKSI PENGUMUMAN LELANG MELALUI MEDIA SURAT KABAR HARIAN PADA LELANG NONEKSEKUSI SUKARELA

Aditya Wirawan ${ }^{1}$ dan Donarin ${ }^{2}$

lelang melalui surat kabar biasa dilakukan oleh pemerintah yang melakukan atas lelang atas aset pemerintah, barang sitaan polisi, hasil hutan, dan lain sebagainya. Jarang terdapat pengumuman lelang pada surat kabar yang memuat lelang atas barang milik privat.

Satu hal yang menarik, di Bangladesh terdapat situs yang berfungsi sebagai basis data informasi lelang dan tender yang telah dan akan dilaksanakan di negara tersebut. Keberadaan situs tersebut jelas memudahkan masyarakat untuk memperoleh informasi pelaksanaan lelang dan tender. Berkaitan dengan lelang, situs tersebut menyediakan informasi pelaksanaan berbagai jenis lelang baik lelang dari pemerintah, semi pemerintah, ataupun privat/swasta. Alltender.com dan bdtender.com merupakan contoh dari situs tersebut. Situs-situs tersebut dimiliki dan dikelola oleh swasta. Informasi pelaksanaan lelang tersedia secara gratis pada laman situs tersebut. Akan tetapi, jika ingin mendapatkan informasi secara langsung melalui e-mail atau telepon, masyarakat perlu membayar biaya berlangganan pada situs tersebut.

Dari ketiga negara tersebut, terdapat beberapa hal yang dapat diadopsi oleh pemerintah untuk meningkatkan efektivitas dan efisiensi pengumuman lelang noneksekusi sukarela. Pertama adalah terkait bagaimana penyebarluasan informasi lelang itu seharusnya dilakukan. Karena tujuan utama adanya pengumuman lelang adalah penyebarluasan informasi lelang, sudah selayaknya penjual diberikan fleksibilitas memilih media yang menurut mereka efektif dan efisien guna mencapai tujuan tersebut. Kedua adalah terkait situs informasi pelaksanaan lelang. Hal tersebut masih relevan untuk diadopsi oleh pemerintah walaupun praktiknya dilakukan di negara yang memiliki sistem hukum yang berbeda dengan Indonesia. Dengan adanya situs tersebut, penyebarluasan informasi lelang kepada masyarakat menjadi lebih efektif karena masyarakat menjadi lebih mudah untuk mendapatkan informasi terkait lelang. Masyarakat hanya perlu membuka satu situs dan di dalamnya telah tersedia informasi pelaksanaan berbagai jenis lelang termasuk lelang noneksekusi sukarela.

\subsection{Preferensi Penjual pada Lelang Noneksekusi Sukarela dalam Melakukan Pengumuman Lelang}

Pengumuman lelang menunjang terwujudnya transparansi dan kompetisi dalam pelaksanaan lelang. Pada prinsipnya pengumuman lelang bertujuan untuk menyebarluaskan informasi lelang kepada khalayak umum. Dengan hal tersebut, diharapkan peserta lelang akan menjadi lebih banyak dan terjadi kompetisi di dalamnya sehingga tercipta harga yang lebih tinggi.

Sejatinya penyebarluasan informasi lelang tidak dibatasi hanya dengan melakukan pengumuman lelang. Penjual dibebaskan menggunakan mediamedia yang lain untuk memperluas jangkauan informasi terkait lelang. Media-media lain tersebut misalnya katalog barang, promosi di media sosial, atau pun lewat komunikasi informal.

PT JBA Indonesia sebagai salah satu contoh penjual pada lelang noneksekusi sukarela berbentuk balai lelang yang telah beroperasi sejak 2011 memiliki beberapa media yang digunakan untuk menyebarluaskan informasi lelang. Berdasarkan penjelasan dari Bapak Michael Philipus selaku Marketing and Customer Care Section Head PT JBA Indonesia, secara garis besar mereka memiliki dua media penyebarluasan informasi lelang yaitu online dan offline.

Secara online, mereka melakukan penyebarluasan informasi lelang melalui website serta media sosial seperti Instagram, Facebook, dan Youtube. Di dalam website resmi PT JBA, selain terdapat jadwal lelang bulanan juga terdapat katalog lelang. Katalog tersebut berisi rincian informasi barang yang akan dilelang dan informasi terkait pelaksanaan lelang. Rincian informasi barang yang dimuat dalam katalog diantaranya merk, tipe, warna, nomor polisi kendaraan, dan lain-lain sedangkan informasi terkait pelaksanaan lelang diantaranya nilai limit barang, lokasi lelang, nomor lot, waktu pelaksanaan lelang, dan catatan tambahan lainnya.

Secara offline, PT JBA Indonesia menggunakan sales promotion item dan legal announcement. Sales promotion item ini berupa flyer, banner, poster, dan katalog fisik. Sedangkan legal announcement ini berupa pengumuman lelang dalam surat kabar harian sesuai peraturan yang telah ditetapkan pemerintah.

Selain melalui media online dan offline tersebut, penyebarluasan informasi lelang juga didukung oleh adanya Tim Customer Care. Tim inilah yang memberikan informasi lelang yang akan dilaksanakan secara langsung pada calon peserta lelang potensial yang sudah sering mengikuti lelang sebelumnya.

Menurut Bapak Michael selaku narasumber, untuk saat ini media offline masih lebih efektif untuk menarik minat calon peserta lelang jika dibanding media online. Hal ini dapat terjadi mengingat peserta pada lelang diadakan JBA sebagian besar adalah pemain dalam bisnis jual beli otomotif bekas. Mereka biasanya berkunjung ke kantor cabang untuk mencari dan mendapatkan informasi secara langsung dengan melihat langsung unit barang dan banner serta membaca flyer, poster, atau katalog fisik yang 
REKONSTRUKSI PENGUMUMAN LELANG MELALUI MEDIA SURAT KABAR HARIAN PADA LELANG

NONEKSEKUSI SUKARELA

Aditya Wirawan ${ }^{1}$ dan Donarin ${ }^{2}$

memang disediakan oleh masing-masing kantor cabang untuk diberikan secara gratis kepada yang memintanya. Selain itu, segmentasi pasar balai lelang ini belum menyasar anak muda yang lebih akrab dengan dunia digital. Maka dari itu, walaupun media online lebih baik dari sisi efisiensi, dari sisi efektivitas media tersebut masih kalah dengan media offline. Akan tetapi, Bapak Michael tidak menutup kemungkinan di masa yang akan media online akan menjadi lebih efektif untuk menyebarluaskan informasi lelang.

"Menurut saya yang paling signifikan sebenernya, untuk saat ini ya, tetep yang offline sih. Kenapa? Karena segmentasi saat ini, market kita belum terlalu ke arah digital. Jadi segmentasi customer kita pun bukan anak-anak muda, banyaknya lebih ke menengah ke atas ya. Untuk umurnya lebih ke menengah ke tua. Jadi e.... pemain-pemain mobil di jaman sekarang ini masih banyak, e.... mobil bekas ya terutama itu banyaknya masih di menengah ke atas. Maka dari itu, jadi masih lebih e.... berperan yang offline daripada yang online. Walaupun mungkin, kita bicara 2 tahun, 3 tahun, 5 tahun, 10 tahun ke depan, mungkin digital lebih berperan, tapi kalau saat ini masih di offline sih menurut saya, walaupun di offline ini kalau dijabarkan e.... ada tingkatannya juga. Misalkan dari flyer, dari poster, apapun yang kita tempelkan di cabang, $x$ banner dan lain-lain itu paling menarik, karena mereka lebih terjun langsung, dateng langsung ke tempat lelang." (Wawancara dengan Bapak Michael Philipus, Marketing and Customer Care Section Head PT JBA Indonesia, tanggal 10 April 2020, Pukul 10.00)

Walaupun media offline dianggap lebih efektif, di dalamnya terdapat media yang dirasa kurang efektif dan kurang efisien dibanding media offline lainnya atau pun media online. Media tersebut adalah surat kabar harian. Narasumber menyatakan bahwa surat kabar harian:

“...tingkat efektifitasnya memang tidak efektif walaupun biayanya cukup besar." (Wawancara dengan Bapak Michael Philipus, Marketing and Customer Care Section Head PT JBA Indonesia, tanggal 10 April 2020, Pukul 10.00)

Berdasarkan penuturan narasumber dalam satu kali event lelang baik motor atau mobil di satu kantor cabang, biaya yang dikeluarkan untuk legal announcement mencapai angka hingga sekitar tiga juta rupiah. PT JBA sendiri memiliki dua event lelang

\footnotetext{
11 Tesano, "Hirarkhisitas Kedudukan Peraturan Menteri Dengan Peraturan Daerah dalam Sistem Peraturan
}

yaitu lelang motor dan lelang mobil serta 18 kantor cabang. Dalam satu bulan, suatu kantor cabang bisa menggelar beberapa kali lelang baik untuk event lelang motor maupun mobil. Maka dari itu, PT JBA Indonesia harus mengeluarkan biaya yang besar untuk melakukan legal announcement melalui media surat kabar harian. Biaya tersebut dirasa tidak sebanding dengan jangkauan penyebarluasan informasi yang ditimbulkannya mengingat pembaca surat kabar yang tidak sebanyak dulu. Terlepas dari masalah tersebut, pengumuman lelang melalui surat kabar harian tetap harus dilakukan oleh penjual lelang karena pengumuman lelang ini merupakan suatu kewajiban yang telah ditetapkan pemerintah.

Pengumuman lelang melalui surat kabar harian ini sebenarnya tidak begitu disukai penjual. Penjual cenderung memilih media offline berupa flyer, poster, maupun katalog fisik untuk melakukan penyebarluasan informasi lelang. Selain itu, media online juga dilirik oleh penjual karena kedepannya teknologi informasi dan komunikasi pasti berkembang sejalan dengan perkembangan zaman.

\subsection{Kedudukan, Kekuatan, dan Rekonstruksi Hukum Peraturan terkait Pengumuman Lelang Noneksekusi Sukarela melalui Media Surat Kabar Harian}

Negara Indonesia adalah negara hukum. Pernyataan tersebut didasarkan pada pasal 1 ayat (3) Undang-undang Dasar Negara Republik Indonesia Tahun 1945. Maka dari itu, seluruh aspek kehidupan di Indonesia harus senantiasa berdasarkan hukum. Untuk mewujudkannya diperlukan peraturan perundang-undangan yang ditata sedemikian rupa dalam suatu hierarki untuk menentukan kedudukan dan kekuatan dari masing-masing peraturan.

Menurut pasal 7 ayat (1) Undang-undang Nomor 12 Tahun 2011 sebagaimana yang telah diubah dengan Undang-undang Nomor 15 Tahun 2019, hierarki peraturan perundang-undangan di Indonesia adalah sebagai berikut:

1. Undang-undang Dasar,

2. Ketetapan MPR,

3. Undang-undang/Peraturan Pemerintah Pengganti Undang-undang,

4. Peraturan Pemerintah,

5. Peraturan Presiden,

6. Peraturan Daerah Provinsi,

7. Peraturan Daerah Kabupaten/Kota.

Nomor urut dalam hierarki tersebut terkait langsung dengan levelitas suatu peraturan perundangundangan (Tesano, 2015) ${ }^{11}$. Artinya, Undang-undang

Perundang-undangan Ditinjau dari Undang-undang Nomor 12 Tahun 2011", Jurnal Nestor Magister Hukum

Halaman 8 
REKONSTRUKSI PENGUMUMAN LELANG MELALUI MEDIA SURAT KABAR HARIAN PADA LELANG

NONEKSEKUSI SUKARELA

Aditya Wirawan ${ }^{1}$ dan Donarin ${ }^{2}$

Dasar yang berada di nomor urut satu merupakan peraturan perundang-undangan yang tertinggi. Undang-undang yang berada di nomor urut dua kedudukannya di bawah Undang-undang Dasar, begitu seterusnya. Peraturan perundang-undangan yang kedudukannya lebih tinggi menjadi sumber bagi peraturan-peraturan yang lebih rendah. Peraturan yang kedudukannya lebih rendah merupakan penjabaran dari peraturan perundang-undangan yang lebih tinggi. Maka dari itu, secara teori antar peraturan perundang-undangan tersebut haruslah sinergis dan tidak boleh bertentangan.

Peraturan perundang-undangan yang terbentuk di Indonesia dipengaruhi berbagai sistem hukum yang pernah dan tengah ada di Indonesia seperti Civil Law sebagai akibat penjajahan Belanda, hukum adat yang berakar dari bangsa Indonesia sendiri, dan hukum Islam berkembang dalam masyarakat. Berdasarkan pasal II aturan peralihan Undang-undang Dasar Negara Indonesia Tahun 1945 semua badan negara dan peraturan yang ada masih berlaku selama belum diadakan yang baru. Maka dari itu, beberapa peraturan perundang-undangan yang telah ada sebelum kemerdekaan Indonesia tetap berlaku hingga saat ini guna menghindari adanya kekosongan hukum.

Salah satu contoh produk hukum kolonial yang berlaku hingga saat ini adalah Vendu Reglement yang lazim disebut sebagai Undang-undang Lelang. Vendu Reglement sebenarnya merupakan peraturan setingkat dengan peraturan pemerintah (Usman, 2016) ${ }^{12}$. Akan tetapi, karena hingga saat ini Vendu Reglement menjadi peraturan lelang yang tertinggi maka tidak salah jika disebut sebagai Undang-undang Lelang. Hingga saat ini Pemerintah Indonesia belum menetapkan peraturan perundang-undangan baru sebagai pengganti Vendu Reglement. Pemerintah memilih untuk menangkap dan merumuskan perkembangan zaman dan perubahan dalam masyarakat dalam peraturan berupa peraturan menteri dan peraturan direktur jenderal.

Membahas pengumuman lelang noneksekusi sukarela, ketentuan terkait hal tersebut sebenarnya tidak diatur secara tegas dalam Vendu Reglement. Pasal 20 alinea 6 Vendu Reglement yang berbunyi:

"Penjualan karena keputusan hakim berdasarkan pasal 197 Reglemen Indonesia, atau pasal 208 Reglemen Acara Hukum untuk Daerah Luar Jawa dan Madura, mengenai barang-barang tidak bergerak yang disita, tidak dapat dilakukan

Vol 2, No N (2),

http://jurnal.untan.ac.id/index.php/nestor/article/view /10250, hal.3

12 Rachmadi Usman, Hukum Lelang, (Jakarta: Sinar kecuali jika kepada juru lelang diberikan buktibukti pengumuman penjualan, sekurangkurangnya tiga hari sebelum hari penjualan, atau yakin dengan cara lain bahwa pengumuman telah dilakukan sesuai dengan ketentuan undang-undang."

mengisyaratkan bahwa kewajiban menunjukkan adanya bukti pengumuman lelang hanya untuk lelang eksekusi benda tidak bergerak sitaan pengadilan sehingga seolah tidak ada kewajiban untuk melakukan pengumuman lelang untuk jenis lelang lainnya.

Pengumuman lelang noneksekusi sukarela diatur sedemikan rupa dalam pasal 58 sampai dengan 61 Peraturan Menteri Keuangan Nomor 27/PMK.06/2016 tentang Petunjuk Pelaksanaan Lelang. Salah satu ketentuan yang ada di dalamnya adalah terkait kewajiban bagi penjual untuk melakukan pengumuman lelang melalui media surat kabar harian. Kewajiban penggunaan surat kabar harian sebagai media pengumuman lelang noneksekusi sukarela terdapat dalam pasal 58 dan 59 peraturan menteri tersebut. Pasal-pasal tersebut menyatakan bahwa:

\section{“Pasal 58}

(1) Pengumuman Lelang untuk Lelang Noneksekusi Wajib dan Lelang Noneksekusi Sukarela dilakukan dengan ketentuan sebagai berikut:

a.Lelang barang tidak bergerak atau barang bergerak yang dijual bersama-sama dengan barang tidak bergerak, dilakukan 1 (satu) kali melalui surat kabar harian paling singkat 7 (tujuh) hari kalender sebelum pelaksanaan lelang; b. Lelang barang bergerak dilakukan 1 (satu) kali melalui surat kabar harian paling singkat 5 (lima) hari kalender sebelum pelaksanaan lelang; c. Lelang barang yang mudah busuk/kedaluwarsa pada Lelang Noneksekusi Wajib, dilakukan 1 (satu) kali melalui surat kabar harian dapat dilakukan kurang dari 5 (lima) hari kalender, namun tidak dapat dilakukan kurang dari 1 (satu) hari kalender se belum pelaksanaan lelang.

(2) Pengumuman Lelang untuk Lelang Noneksekusi Wajib dan Lelang Noneksekusi Sukarela yang diulang berlaku ketentuan sebagaimana dimaksud pada ayat (1).

Pasal 59

(1) Pengumuman Lelang untuk pelaksanaan Lelang Noneksekusi Wajib dan Lelang Noneksekusi Sukarela yang Nilai Limit 
REKONSTRUKSI PENGUMUMAN LELANG MELALUI MEDIA SURAT KABAR HARIAN PADA LELANG NONEKSEKUSI SUKARELA

Aditya Wirawan ${ }^{1}$ dan Donarin ${ }^{2}$

keseluruhannya paling banyak Rp50.000.000,00 (lima puluh juta rupiah) dalam 1 (satu) kali lelang, dapat dilakukan 1 (satu) kali melalui tempelan yang mudah dibaca oleh umum dan/ atau melalui media elektronik, paling singkat 5 (lima) hari kalender sebelum hari pelaksanaan lelang.

(2) Ketentuan sebagaimana dimaksud pada ayat

(1) berlaku dalam hal ada permintaan tertulis dari Penjual dengan menyebutkan alasan mengumumkan melalui tempelan yang mudah dibaca oleh umum dan/ atau melalui media elektronik.

(3) Pengumuman Lelang Ulang untuk pelaksanaan Lelang Noneksekusi Wajib dan Lelang Noneksekusi Sukarela dengan Nilai Limit keseluruhan paling banyak Rp50.000.000,00 (lima puluh juta rupiah) dalam 1 (satu) kali lelang, berlaku ketentuan sebagaimana dimaksud pada ayat (1)."

Dari kedua pasal tersebut dapat diketahui bahwa penjual wajib melakukan pengumuman lelang noneksekusi sukarela melalui media surat kabar harian dalam hal:

1. Lelang maupun lelang ulang barang bergerak, barang tidak bergerak, atau barang bergerak yang dijual bersama dengan barang tidak bergerak dengan nilai limit lebih dari Rp50.000.000,00;

2. Lelang maupun lelang ulang dengan nilai limit paling banyak Rp50.000.000,00 tanpa disertai permintaan tertulis dari penjual untuk melakukan pengumuman lelang melalui tempelan yang mudah dibaca oleh umum dan atau melalui media elektronik.

Ketentuan tersebut mengindikasikan bahwa pemerintah telah memberikan hak istimewa kepada pelaku usaha industri surat kabar harian sebagai media utama untuk melakukan pengumuman lelang. Adanya hak istimewa tersebut jelas menimbulkan perbedaan kesempatan berusaha bagi pelaku usaha industri lainnya yang sebenarnya dapat menjalankan fungsi surat kabar harian sebagai media untuk menyebarluaskan informasi lelang. Sebagai negara demokrasi, pemerintah sudah seharusnya menciptakan keadilan terkait akses ekonomi bagi semua orang untuk dapat hidup sejahtera. Demokrasi mengakomodasi masyarakat untuk memperjuangkan hak-hak ekonominya termasuk akses untuk dapat berekonomi secara efisien.

Pemberian hak istimewa tersebut sebenarnya bertentangan dengan tujuan pembentukan Undangundang Nomor 5 Tahun 1999 Tentang Larangan Praktek Monopoli dan Persaingan Usaha Tidak Sehat. Pada pasal 3 disebutkan bahwa salah satu tujuan pembentukan undang-undang tersebut adalah untuk mewujudkan iklim usaha yang kondusif sehingga menjamin adanya kepastian kesempatan berusaha yang sama bagi semua orang baik pelaku usaha besar, pelaku usaha menengah, dan pelaku usaha kecil. Adanya pertentangan tersebut menunjukkan adanya disharmoni antara peraturan menteri yang mengatur pengumuman lelang noneksekusi sukarela dengan peraturan perundang-undangan yang lain.

Pasal 8 ayat (1) dan (2) Undang Undang Nomor 12 Tahun 2011 sebagaimana yang telah diubah dengan Undang-undang Nomor 15 Tahun 2019 menyatakan bahwa selain peraturan perundangundangan yang ada dalam hierarki terdapat peraturan perundang-undangan lainnya. Peraturan perundangundangan lainnya tersebut mencakup peraturan yang ditetapkan oleh MPR, DPR, DPD, MA, MK, KY, BPK, BI, menteri, badan, lembaga, atau komisi yang setingkat yang dibentuk dengan undang-undang atau pemerintah atas perintah undang-undang, DPRD Provinsi, Gubernur, DPRD Kabupaten/Kota, Bupati/Walikota, serta Kepala Desa atau yang setingkat. Selanjutnya pada ayat (2) disebutkan bahwa peraturan perundang-undangan lainnya tersebut diakui keberadaannya dan memiliki kekuatan hukum mengikat sepanjang diperintahkan oleh peraturan perundang-undangan yang lebih tinggi atau dibentuk berdasarkan kewenangan.

Dari pasal tersebut dapat diketahui bahwa peraturan menteri termasuk peraturan perundangundangan lainnya yang memiliki kekuatan hukum mengikat karena peraturan tersebut dibentuk berdasarkan kewenangan derevatif atau delegatif dari presiden yang melekat pada jabatan menteri. Akan tetapi, kedudukan peraturan menteri dalam hierarki peraturan perundang-undangan tidak disebutkan secara jelas sehingga secara formal posisi peraturan menteri ini tidak dapat dipastikan.

Pasal 17 Undang-undang Dasar Negara Republik Indonesia Tahun 1945 menjelaskan bahwa para menteri diangkat oleh presiden untuk membatu tugas-tugasnya. Dari pernyataan tersebut dapat diketahui bahwa peraturan yang dikeluarkan menteri kedudukannya lebih rendah daripada peraturan yang dikeluarkan oleh presiden atau yang biasa disebut Peraturan Presiden. Jadi, peraturan menteri kedudukannya lebih rendah dibanding Undangundang Dasar Negara Republik Indonesia Tahun 1945, Ketetapan MPR, Undang-undang/ PERPU, Peraturan Pemerintah, dan Peraturan Presiden.

Menteri merupakan pembantu presiden yang bekedudukan di pemerintahan pusat. Maka dari itu, peraturan-peraturan yang dikeluarkannya berlaku secara nasional. Jika dibandingkan dengan Peraturan Daerah yang berlaku secara lokal terbatas pada 
REKONSTRUKSI PENGUMUMAN LELANG MELALUI MEDIA SURAT KABAR HARIAN PADA LELANG NONEKSEKUSI SUKARELA

Aditya Wirawan ${ }^{1}$ dan Donarin ${ }^{2}$

daerah provinsi atau kabupaten/kota tertentu, peraturan menteri jangkauannya lebih luas sehingga kedudukannya pun lebih tinggi dari pada Peraturan Daerah Provinsi dan Peraturan Daerah Kabupaten/Kota. Hal tersebut sejalan dengan pendapat Tesano bahwa kedudukan peraturan menteri mempunyai derajat yang lebih tinggi dari peraturan daerah ${ }^{13}$.

Vendu Reglement yang berkedudukan setingkat Peraturan Pemerintah dapat dijadikan sumber bagi pembentukan berbagai peraturan menteri keuangan terkait lelang seperti Peraturan Menteri Keuangan Nomor 27/PMK.06/2016 tentang Petunjuk Pelaksanaan Lelang. Ketentuan-ketentuan dalam peraturan menteri tersebut merinci serta melengkapi hal-hal yang tidak tercantum dalam Vendu Reglement. Walaupun peraturan perundang-undangan tersebut tidak memerintahkan pembentukan aturan pelaksanaan, Peraturan Menteri Keuangan tersebut tetap berkedudukan sebagai peraturan perundangundangan yang berkekuatan hukum mengikat karena peraturan tersebut dibentuk berdasarkan kewenangan Menteri Keuangan.

Jika berkaca pada Pembukaan Undang-undang Dasar Negara Republik Indonesia Tahun 1945, Vendu Reglement sebenarnya sudah tidak relevan dengan tujuan negara setelah Indonesia merdeka. Vendu Reglement dibuat berdasarkan keinginan dan kebutuhan pemerintah Hindia Belanda untuk melindungi kepentingan para pemilik modal atau kreditur dan Pejabat Belanda serta untuk memperbesar penerimaan pemerintah dari sektor pajak lelang. Setelah Indonesia merdeka, lelang menjadi salah satu faktor penunjang pembangunan perekonomian nasional. Secara tidak langsung, lelang menjadi sarana untuk mencapai salah satu tujuan negara yaitu memajukan kesejahteraan umum.

Undang-undang Dasar Negara Republik Indonesia Tahun 1945 merupakan peraturan perundang-undangan tertinggi sehingga semua peraturan perundang-undangan di bawahnya harus bersumber padanya. Maka dari itu, pemerintah perlu membentuk peraturan perundang-undangan baru yang sejalan dengan tujuan negara tersebut untuk menggantikan Vendu Reglement. Peraturan perundang-undangan baru ini akan menjadi sumber bagi aturan pelaksanaan lelang sehingga aturan tersebut juga akan sejalan dengan tujuan negara.

Undang-undang dapat dipilih menjadi bentuk peraturan perundang-undangan baru pengganti Vendu Reglement. Pertimbangan pemilihan bentuk undang-undang tersebut adalah sebagai berikut:
1. Lelang menjadi salah satu alat yang digunakan dalam penuntasan berbagai permasalahan hukum yang diamanatkan dalam berbagai undang-undang misalnya seperti KUH Perdata, HIR dan RBG, KUH Acara Pidana, Undang-undang Nomor 49 Prp. Tahun 1960 tentang Panitia Urusan Piutang Negara, Undang-undang Nomor 4 tahun 1996 tentang Hak Tanggungan, dan sebagainya sehingga peraturan terkait lelang juga perlu dibuat setingkat dengan peraturan-peraturan tersebut yang berbentuk undang-undang;

2. Bentuk sebagai undang-undang menjadikan suatu peraturan menjadi peraturan terkuat setelah Undang-undang Dasar dan lebih fleksibel untuk menjadi sumber bagi peraturan perundangundangan lain.

Pasal 10 ayat (1) Undang-undang Nomor 12 Tahun 2011[u6] tentang Pembentukan Peraturan Perundang-undangan sebagaimana yang telah diubah dengan Undang-undang Nomor 15 Tahun 2019 menyatakan salah satu materi muatan yang harus diatur dalam undang-undang adalah pemenuhan kebutuhan hukum dalam masyarakat. Kebutuhan hukum dalam masyarakat tersebut dilihat dari beberapa aspek yaitu dari aspek kepastian hukum, keadilan, dan kemanfaatan.

Aspek kepastian hukum menjamin adanya kepastian dan perlindungan hukum bagi pihak-pihak yang berkepentingan dalam pelaksanaan lelang. Dalam Vendu Reglement tidak ada pembatasan jenis tuntutan yang diperkenankan dan siapa yang harus bertanggung jawab atas tuntutan tersebut. Hal tersebut mengakibatkan beragamnya tuntutan yang diajukan penggugat dalam gugatannya yang salah satunya terkait pengumuman lelang. Gugatan tersebut berpotensi untuk membatalkan lelang. Jika lelang dibatalkan, objek lelang akan kembali ke keadaan semula dan tidak ada jaminan dan perlindungan bagi pemenang lelang atas objek lelang yang telah dimenangkannya. Dari hal tersebut dapat diketahui bahwa belum ada kepastian hukum dalam peraturan perundang-undangan tersebut. Maka dari itu, pemerintah sebagai regulator perlu memberikan kepastian hukum dengan pembatasan jenis tuntutan apa yang diperkenankan dalam gugatan serta siapa yang harus bertanggung jawab atasnya. Tuntutan terhadap lelang seharusnya terbatas pada tuntutan ganti kerugian. Kemudian pihak yang bertanggung jawab mengganti kerugian tersebut adalah penjual/pemohon lelang.

Aspek keadilan menghendaki bahwa dalam proses pelaksanaan lelang harus dapat memenuhi

${ }^{13}$ Tesano, Loc.Cit., hal.18. 
REKONSTRUKSI PENGUMUMAN LELANG MELALUI MEDIA SURAT KABAR HARIAN PADA LELANG NONEKSEKUSI SUKARELA

Aditya Wirawan ${ }^{1}$ dan Donarin ${ }^{2}$

rasa keadilan secara proposional bagi setiap pihak yang berkepentingan. Aspek ini berfungsi untuk mencegah keberpihakan pada satu pihak. Ketentuan dalam undang-undang yang baru harus dapat membuka persaingan antar pelaku usaha yang bergerak di bidang penyebarluasan informasi. Hal ini dapat diwujudkan dengan memberikan kebebasan bagi penjual untuk memilih media pengumuman lelang. Pengumuman lelang dapat dilakukan melalui papan pengumuman, media daring, atau situs web penyelenggara lelang, tidak hanya terbatas dengan surat kabar harian.

Aspek manfaat mengandung pengertian bahwa lelang harus dapat memberikan manfaat kepada pengguna jasa lelang dan masyarakat luas. Rancangan undang-undang yang baru harus menangkap perkembangan dalam masyarakat. Salah satunya adalah dengan menjadikan e-marketplace sebagai salah satu penyelenggara lelang. Kemudian upload informasi lelang pada situs web penyelenggara lelang tersebut sudah dianggap sebagai pengumuman lelang. Hal tersebut akan mengurangi biaya yang harus dikeluarkan penjual untuk melakukan pengumuman lelang. Selain itu, hal tersebut juga akan mendorong pertumbuhan lelang pada e-marketplace yang pada akhirnya akan meningkatkan pertumbuhan ekonomi masyarakat secara lebih luas.

Kemudian dalam rangka memajukan kesejahteraan umum, rancangan undang-undang baru juga harus mengatur hak dan kewajiban pihakpihak dalam pelaksanaan lelang. Negara hadir sebagai pembina, pengelola, dan penyelenggara lelang sedangkan warga negara bertindak sebagai pemohon atau pun pemenang lelang. Adanya ketentuan tersebut bertujuan untuk memperjelas hak dan kewajiban masing-masing pihak dalam pelaksanaan lelang yang belum diatur secara rinci oleh Vendu Reglement.

Pembentukan undang-undang untuk menggantikan Vendu Reglement harus dilakukan sesuai dengan pertimbangan dan materi muatan yang telah dipaparkan sebelumnya. Dalam pembentukan undang-undang baru tersebut, pemerintah perlu melakukan upaya sinkronisasi dan harmonisasi dengan undang-undang yang lain. Upaya tersebut dilakukan untuk menghindari tumpang tindih peraturan yang pada akhirnya dapat mengganggu tujuan pembentukan masing-masing undang-undang baik yang baru maupun yang telah ada sebelumnya.

\section{KESIMPULAN DAN SARAN}

Penjual dihadapkan pada masalah terkait efektivitas dan efisiensi dalam melaksanakan pengumuman lelang noneksekusi sukarela melalui media surat kabar harian. Surat kabar harian dianggap kurang efektif untuk dapat mencapai tujuan utama pengumuman lelang untuk menyebarluaskan informasi lelang. Kebiasaan masyarakat untuk mengakses informasi tidak lagi didominasi oleh kegiatan membaca surat kabar harian. Kebiasaan tersebut telah bergeser ke arah membaca media online yang diakses melalui internet. Surat kabar harian juga dianggap kurang efisien. Penjual harus mengeluarkan biaya yang cukup besar untuk memuat pengumuman lelang pada media tersebut. Bahkan, biaya tersebut bertambah ketika penjual harus melakukan ralat pengumuman lelang. Dari negara Republik Rakyat Tiongkok, Jepang, dan Bangladesh, terdapat beberapa hal yang dapat diadopsi oleh pemerintah Indonesia untuk meningkatkan efektivitas dan efisiensi pengumuman lelang noneksekusi sukarela. Pemerintah melalui regulasinya dapat memberikan fleksibilitas kepada penjual untuk memilih media pengumuman lelang. Pemerintah juga dapat mengembangkan situs informasi pelaksanaan lelang yang memudahkan masyarakat untuk memperoleh informasi lelang.

Akibat masalah tersebut, media surat kabar harian tidak begitu disukai oleh penjual. Penjual cenderung memilih media offline berupa flyer, poster, maupun katalog fisik untuk melakukan penyebarluasan informasi lelang. Selain itu, media online juga dilirik oleh penjual dengan pertimbangan bahwa ke depannya teknologi informasi dan komunikasi pasti berkembang sejalan dengan perkembangan zaman. Meskipun begitu, pengumuman lelang noneksekusi sukarela melalui media surat kabar harian wajib dilakukan oleh penjual untuk memenuhi aspek hukum lelang.

Pengumuman lelang noneksekusi sukarela melalui media surat kabar harian diatur dalam peraturan berbentuk peraturan menteri. Peraturan menteri berkedudukan sebagai peraturan perundangundangan lainnya. Kedudukan tersebut diatur dalam pasal 8 Undang-undang Nomor 12 Tahun 2011 sebagaimana yang telah diubah dengan Undangundang Nomor 15 Tahun 2019. Peraturan menteri juga memiliki kekuatan hukum yang mengikat karena peraturan tersebut dibentuk berdasarkan kewenangan yang ada pada menteri. Walaupun memiliki kekuatan hukum yang mengikat, terdapat beberapa kelemahan dalam peraturan tersebut. Kelemahan-kelemahan tersebut diantaranya:

a. Vendu Reglement yang merupakan sumber hukum peraturan menteri tersebut sudah tidak sejalan dengan Undang-undang Dasar Negara Republik Indonesia Tahun 1945 yang merupakan sumber 
REKONSTRUKSI PENGUMUMAN LELANG MELALUI MEDIA SURAT KABAR HARIAN PADA LELANG

NONEKSEKUSI SUKARELA

Aditya Wirawan ${ }^{1}$ dan Donarin ${ }^{2}$

hukum tertinggi di Indonesia. Tujuan pembentukan Vendu Reglement sudah tidak sejalan dengan tujuan negara yang termuat dalam Pembukaan Undang-undang Dasar Negara Republik Indonesia Tahun 1945;

b. Terdapat disharmoni antara peraturan tersebut dengan peraturan perundang-undangan lain. Ketentuan pengumuman lelang melalui media surat kabar harian dalam peraturan menteri yang bersumber pada Vendu Reglement tersebut mengindikasikan adanya keberpihakan pemerintah pada satu pelaku usaha tertentu yaitu industri surat kabar harian. Pasal 58 dan 59 Peraturan Menteri Keuangan Nomor 27/PMK.06/2016 dan pasal 20 alinea 6 Vendu Reglement tidak selaras dengan tujuan pembentukan undang-undang yang lain yang tercantum pada pasal 3 Undang-undang Nomor 5 Tahun 1999 tentang Larangan Praktek Monopoli dan Persaingan Usaha Tidak Sehat.

Pemerintah perlu membentuk peraturan perundang-undangan baru berupa undang-undang terkait lelang untuk mememenuhi kebutuhan hukum dalam masyarakat. Berdasarkan pasal 10 ayat (1) Undang-undang Nomor 12 Tahun 2011 sebagaimana yang telah diubah dengan Undang-undang Nomor 15 Tahun 2019, salah satu materi muatan yang harus diatur dalam undang-undang adalah pemenuhan kebutuhan hukum dalam masyarakat. Kebutuhan hukum dalam masyarakat tersebut dilihat dari beberapa aspek yaitu aspek kepastian hukum, keadilan, dan kemanfaatan. Aspek kepastian hukum menjamin adanya kepastian dan perlindungan hukum bagi pihak-pihak yang berkepentingan dalam pelaksanaan lelang. Pemerintah sebagai regulator perlu memberikan pembatasan jenis tuntutan apa yang diperkenankan dalam gugatan serta siapa yang harus bertanggung jawab atasnya. Aspek keadilan menghendaki bahwa dalam proses pelaksanaan lelang harus dapat memenuhi rasa keadilan secara proposional bagi setiap pihak yang berkepentingan. Ketentuan dalam undang-undang yang baru harus dapat membuka persaingan antar pelaku usaha yang bergerak di bidang penyebarluasan informasi. Aspek manfaat mengandung pengertian bahwa lelang harus dapat memberikan manfaat kepada pengguna jasa lelang dan masyarakat luas. Dengan menyederhanakan ketentuan terkait pengumuman lelang, pemerintah dapat mengurangi biaya yang harus dikeluarkan penjual untuk melakukan pengumuman lelang. Selain itu, dengan melibatkan $e$ marketplace sebagai penyelenggara lelang akan dapat meningkatkan pertumbuhan ekonomi masyarakat secara lebih luas. Undang-undang baru tersebut juga harus mengatur hak dan kewajiban pihak-pihak dalam pelaksanaan lelang untuk memperjelas hak dan kewajiban masing-masing pihak belum diatur secara rinci oleh Vendu Reglement.

Selain karena materi muatan, undang-undang menjadi bentuk yang paling tepat untuk memberikan pengaturan baru terkait lelang dengan pertimbangan sebagai berikut:

a. Lelang menjadi salah satu alat yang digunakan dalam penuntasan berbagai permasalahan hukum yang diamanatkan dalam berbagai undang-undang sehingga peraturan terkait lelang juga perlu dibuat setingkat dengan peraturan-peraturan tersebut yang berbentuk undang-undang;

b. Bentuk sebagai undang-undang menjadikan suatu peraturan menjadi peraturan terkuat setelah Undang-undang Dasar dan lebih fleksibel untuk menjadi sumber bagi peraturan perundangundangan lain.

Dalam pembentukan undang-undang baru tersebut, pemerintah perlu melakukan upaya sinkronisasi dan harmonisasi dengan undang-undang yang lain. Upaya tersebut dilakukan untuk menghindari tumpang tindih peraturan yang pada akhirnya dapat mengganggu tujuan pembentukan masing-masing undang-undang baik yang baru maupun yang telah ada sebelumnya.

Berdasarkan kesimpulan yang telah diambil, Penulis menawarkan beberapa saran. Berkaitan dengan masalah efektivitas dan efisiensi pengumuman lelang noneksekusi sukarela melalui media surat kabar harian pemerintah dapat memberikan keleluasaan kepada pihak penjual untuk memilih media yang mereka gunakan sebagai media pengumuman lelang. Hal tersebut diharapkan dapat mengurangi biaya yang harus dikeluarkan oleh penjual dalam melakukan pengumuman lelang. Keleluasaan tersebut dapat diberikan dengan menghapus ketentuan kewajiban penggunaan media surat kabar harian dan menggantinya dengan ketententuan penggunaan media lain yang lebih efektif dan efisien menurut penjual. Kemudian pemerintah juga dapat membangun dan mengembangkan suatu situs pusat informasi yang terintegrasi terkait pelaksanaan lelang. Situs tersebut dapat menjadi media yang dipilih oleh penjual untuk memasang pengumuman lelangnya. Selain itu, masyarakat juga dapat lebih mudah untuk mengetahui informasi lelang yang akan dilaksanakan karena semua informasi lelang tersedia dalam satu situs ini. Berkaitan dengan peraturan yang memuat ketentuan pengumuman lelang noneksekusi sukarela melalui surat kabar harian, pemerintah dapat membentuk peraturan perundang-undangan baru berupa undang-undang yang dalam proses 
REKONSTRUKSI PENGUMUMAN LELANG MELALUI

MEDIA SURAT KABAR HARIAN PADA LELANG

NONEKSEKUSI SUKARELA

Aditya Wirawan ${ }^{1}$ dan Donarin ${ }^{2}$

pembentukannya perlu dilakukan upaya sinkronisasi dan harmonisasi dengan undang-undang yang lain untuk menghindari tumpang tindih peraturan.

\section{IMPLIKASI DAN KETERBATASAN}

Keterbatasan dalam penelitian ini adalah jumlah sumber data primer. Penulis hanya menggunakan hasil wawancara dari satu narasumber yang bertindak sebagai penjual lelang. Penelitian lanjutan atas tulisan ini akan lebih baik apabila menggunakan lebih banyak responden ataupun narasumber agar hasil penelitian menjadi lebih menggambarkan keadaan sebenarnya di lapangan.

\section{DAFTAR PUSTAKA (REFERENCES)}

Buku dan Sumber Lainnya:

All Tender. (2020). All Tender: for all Bangladeshi tenders. https://www.alltender.com/

Badan Pengembangan dan Pembinaan Bahasa. (2016). Kamus Besar Bahasa Indonesia Versi Daring. https://kbbi.kemdikbud.go.id/

Bdtender.com. (2020). Bdtender.com: Largest Tender Portal Since 2003. https://bdtender.com/

Friedman, L. M. (2013). The Legal System: A Social Science Perspective, diterjemahkan oleh $M$. Khozim. 2013. Sistem Hukum: Perspektif IImu Sosial (VIII). Penerbit Nusa Media.

Kriyantono, R. (2006). Teknik Praktis Riset Komunikasi. PT Kencana Perdana.

Miles, M. B., \& Huberman, A. M. (2007). Analisis Data Kualitatif. Universitas Indonesia.

Nailufar, N. N. (2019). Akankah TV Bernasib Sama dengan Koran dan Majalah? https://www.kompas.com/tren/read/2019/08/ 24/071300965/akankah-tv-bernasib-samadengan-koran-dan-majalah?page=all

Nielsen.com. (2017). Tren Baru di Kalangan Pengguna Internet di Indonesia. Www.Nielsen.Com. https://www.nielsen.com/id/en/pressreleases/2017/tren-baru-di-kalangan-penggunainternet-di-indonesia/

Osborne, D., \& Gaebler, T. (1992). Reinventing Government: How the Entrepreneurial Spirit is Transforming the Public Sector, diterjemahkan oleh Abdul Rosyid.1996. Mewirausahakan Birokrasi: Mentransformasikan Semangat Wirausaha ke dalam Sektor Publik. Pustaka Binaman Pressido.

Tamete Fuyasu. (2020). おすすめオークションサイ ト・アプリ! 種類 特徵 比較まとめ: Aplikasi Situs Lelang yang Disarankan! Jenis Ringkasan Perbandingan Fitur. https://tamete- fuyasu.com/auction/4314/

Tesano. (2015). Hirarkhisitas Kedudukan Peraturan Menteri dengan Peraturan Daerah dalam Sistem Peraturan Perundang-undangan Ditinjau dari Undang-undang Nomor 12 Tahun 2011. Jurnal Nestor Magister Hukum, Vol 2, No(2). http://jurnal.untan.ac.id/index.php/nestor/artic le/view/10250

The State Council. (2014). Auction Law of the People's Republic of China. http://english.www.gov.cn/archive/laws_regula tions/2014/08/23/content_281474982987372.h tm

Usman, R. (2016). Hukum Lelang. Sinar Grafika.

\section{Peraturan Perundang-undangan:}

Undang-undang Dasar Negara Republik Indonesia 1945.

Burgerlijk Wetboek/ Kitab Undang-undang Hukum Perdata (Stbl. 1847 No.23).

Herzien Inlandsch Reglement (Stbl. 1941 No. 44).

Kitab Undang-undang Hukum Acara Pidana.

Rechtsreglement Buitengewesten (Stbl. 1927 No. 227).

Pemerintah Republik Indonesia. 1960. Undangundang Republik Indonesia Nomor 49 Prp. Tahun 1960 tentang Panitia Urusan Piutang Negara.

1996. Undang-

undang Republik Indonesia Nomor 4 Tahun 1996 tentang Hak Tanggungan.

1999. Undangundang Republik Indonesia Nomor 5 Tahun 1999 tentang Larangan Praktek Monopoli dan Persaingan Usaha Tidak Sehat.

2011. Undangundang Republik Indonesia Nomor 12 Tahun 2011 tentang Pembentukan Peraturan Perundang-undangan.

2019. Undangundang Republik Indonesia Nomor 15 Tahun 2019 tentang Perubahan Undang-undang Nomor 12 Tahun 2011 tentang Pembentukan Peraturan Perundang-undangan.

Vendu Reglement (Stbl. 1908 No. 189).

Kementerian Keuangan. 2016. Peraturan Menteri Keuangan Nomor 27/PMK.06/2016 tentang Petunjuk Pelaksanaan Lelang.

Direktorat Jenderal Kekayaan Negara. 2017. Peraturan Direktur Jenderal Kekayaan Negara Nomor 2/KN/2017 tentang Petunjuk Teknis Pelaksanaan Lelang. 